\title{
Edukasi dan Pendampingan Akuntansi Kader Posyandu Rambutan dan Posyandu Nusa Indah Desa Mekarwangi Kabupaten Tangerang
}

\author{
Bahtiar Effendi \\ Universitas Matana \\ bahtiar.effendi90@gmail.com
}

Naskah diterima: 19 Desember 2019| Naskah disetujui: 10 Januari 2020

\begin{abstract}
This community service activity aims to provide education and assistance to Kader Posyandu Rambutan and Posyandu Nusa Indah in Mekarwangi village, Tangerang, by providing an adequate understanding of effective accounting practices and introduction of financial accounting standards for non-profit organizations (PSAK 45). The method of community service activities is carried out through several stages. The first stage is the assessment of needs. The second stage is the implementation of activities in the form of education and accounting assistance which is carried out through the delivery of material and direct assistance in bookkeeping for Posyandu and discussions. The third stage is monitoring which aims to accommodate the problems experienced by Posyandu during the accounting process. Based on the activities carried out, Kader Posyandu are quite helpful in the bookkeeping process which has been considered difficult due to their lack educational background on elementary and junior high school, so that their competencies need to be improved, therefore Posyandu bookkeeping and/or accounting practices can run effectively and can also improve the timeliness of Posyandu formal reporting to Mekarwangi Village Midwives and Puskesmas (community health center). Community service activities still need to be continued to other Posyandu in Mekarwangi Village so that the competence of accounting among Kader Posyandu can be evenly distributed.
\end{abstract}

Keywords: accounting, posyandu, Mekarwangi village

Abstrak
Kegiatan pengabdian kepada masyarakat ini bertujuan untuk memberikan edukasi dan
pendampingan bagi Kader Posyandu Rambutan dan Posyandu Nusa Indah di Desa Mekarwangi,
Tangerang, dengan memberikan pemahaman memadai tentang praktik pembukuan (akuntansi) yang
efektif dan pengenalan standar akuntansi keuangan organisasi nirlaba (PSAK 45). Metode 
pelaksanaan kegiatan pengabdian kepada masyarakat dilakukan melalui beberapa tahapan. Tahap pertama adalah kegiatan penjajakan kebutuhan. Tahap kedua adalah pelaksanaan kegiatan berupa edukasi dan pendampingan akuntansi yang dilakukan melalui penyampaian materi dan pendampingan langsung pembukuan Posyandu dan diskusi. Tahap ketiga adalah monitoring yang bertujuan untuk menampung permasalahan yang dialami Posyandu selama proses pembukuan (akuntansi). Berdasarkan kegiatan yang dilaksanakan, Kader Posyandu cukup terbantu dalam proses pembukuan yang selama ini dianggap sulit dikarenakan kompetensi pendidikan mereka yang mayoritas SD dan SMP sehingga kompetensinya perlu ditingkatkan agar praktik pembukuan (akuntansi) Posyandu bisa berjalan secara efektif dan dapat meningkatkan ketepatwaktuan pelaporan formal Posyandu kepada Bidan dan Puskesmas Desa Mekarwangi. Kegiatan pengabdian kepada masyarakat masih perlu dilanjutkan ke Posyandu lainnya di Desa Mekarwangi agar kompetensi pembukuan (akuntansi) para Kader Posyandu dapat seimbang.

Kata kunci: akuntansi, posyandu, desa Mekarwangi

\section{Pendahuluan}

Tridharma Perguruan Tinggi yang selanjutnya disebut Tridharma PT merupakan kewajiban Perguruan Tinggi untuk menyelenggarakan pendidikan dan pengajaran, penelitian, dan pengadian kepada masyarakat (UU No. 12 Tahun 2012, Pasal 1 Ayat 9). Berdasarkan peraturan tersebut, Lembaga Penelitian, Pengembangan Ilmu, dan Kajian Teknologi (LP2IKT) Universitas Matana telah melaksanakan kegiatan Tridharma PT secara konsisten.

Universitas Matana telah melaksanakan konsep RBTL (Research Based Teaching and Learning) dimulai pada tahun 2017. Konsep RBTL tersebut telah diimplementasikan dengan cara mengkolaborasikan antara kegiatan pendidikan dan pengajaran di kelas, pengabdian masyarakat dan kegiatan penelitian dengan melibatkan mahasiswa/i Universitas Matana untuk berperan serta aktif dalam menemukan permasalahan, merumuskan solusi dan evaluasi terkait dengan kegiatan pendidikan dan pengajaran yang sudah diterima di kelas guna perbaikan kurikulum dan metode pembelajaran yang sudah diterima. Hal tersebut dibuktikan dengan adanya penandatanganan nota kerjasama (Memo of Understanding) dengan beberapa Desa Binaan atau Mitra Binaan Universitas Matana yakni KTLH Sangga Buana, Jakarta dan Desa Mekarwangi, Cisauk-Tangerang. 

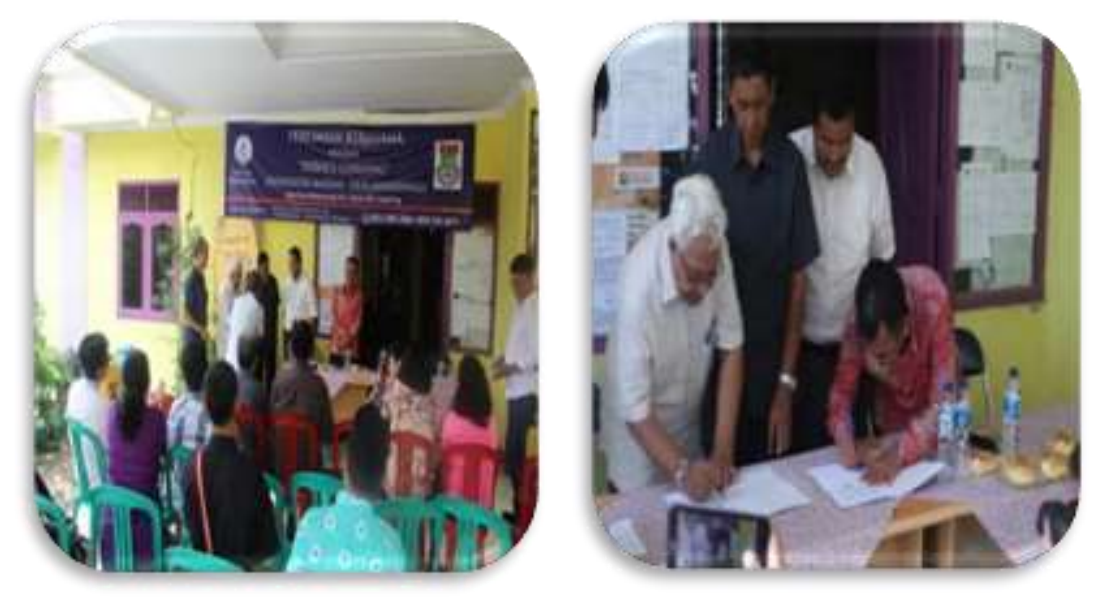

Gambar 1. MoU Universitas Matana-Desa Binaan

Adapun kegiatan rutin yang sudah dilakukan, khususnya di Program Studi Akuntansi, di antaranya adalah pembelajaran akuntansi dasar di SDN Mekarwangi, Cisauk, Kab. Tangerang (Effendi, 2018), pendampingan akuntansi Bendahara dan Pengajar SDN Mekarwangi, Cisauk, Kab. Tangerang (Effendi, 2018) dan kegiatan di tahun 2019 ini yang sedang berjalan adalah pendampingan pembukuan P2WKSS Cilegong Khususnya di Seluruh Posyandu Se-Desa Mekarwangi. Selain kegiatan rutin, terdapat juga kegiatan yang bersifat insidentil yang sudah dilakukan seperti bimbingan dan pelatihan akuntansi dan pajak untuk siswa kelas XII Ak di SMK Dharma Widya, Neglasari, Tangerang-Banten (Effendi, 2018).

Desa Mekarwangi merupakan salah satu desa yang terpencil berlokasi di Kecamatan Cisauk, Kabupaten Tangerang. Desa yang merupakan desa pemekaran dari Kelurahan Cisauk ini sebagaimana ditunjukkan dalam Gambar 2.

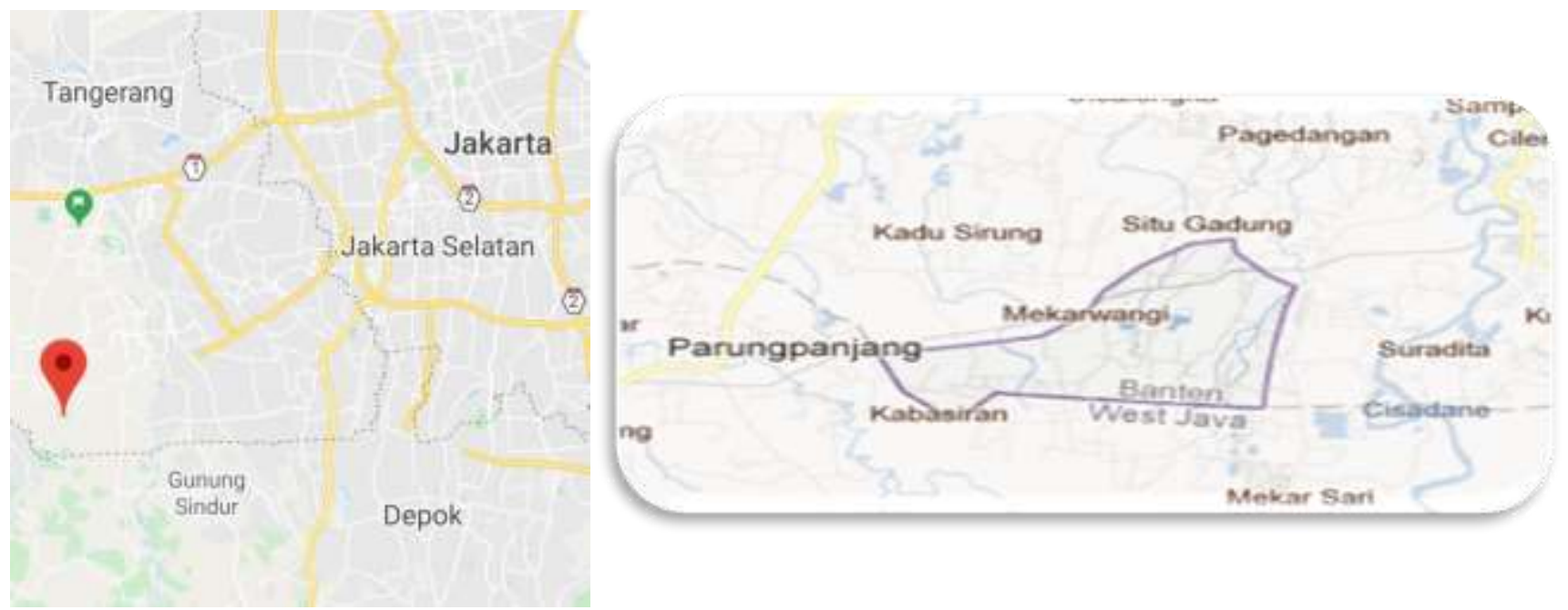

Gambar 2. Peta Desa Mekarwangi, Cisauk-Tangerang 
Desa ini merupakan salah satu desa tertinggal di Kabupaten Tangerang. Sebagian besar penduduknya adalah petani, buruh tani dan pedagang. Selanjutnya, mayoritas penduduk Desa Mekarwangi tidak tamat Sekolah Dasar (SD) berdasarkan Buku Monograf Desa Mekarwangi (2015).

Posyandu Desa Mekarwangi terdiri atas 6 Posyandu, yakni Posyandu Rambutan (Kp. Pasir Awi Rt. 14/05, Ds. Mekarwangi, Kec. Cisauk), Posyandu Nanas (Kp. Cilegong Rt. 02/01, Ds. Mekarwangi, Kec. Cisauk), Posyandu Plamboyan I (Kp. Kandang Rt. 07/03, Ds. Mekarwangi, Kec. Cisauk), Posyandu Plamboyan II (Kp. Kandang Rt. 05/02, Ds. Mekarwangi, Kec. Cisauk), Posyandu Manggis (Kp. Penyirapan Rt. 10/04, Ds. Mekarwangi, Kec. Cisauk), dan Posyandu Nusa Indah (Kp. Lebaksari Rt.10/05, Ds. Mekarwangi, Kec. Cisauk).

Berdasarkan hasil penjajakan kebutuhan bersama yang dilakukan pada tanggal 13 Agustus 2019 bertempat di Desa Mekarwangi antara LPPM dan Dosen Akuntansi Universitas Matana dengan Sekretaris Desa Mekarwangi diperoleh keputusan kebutuhan pendampingan akuntansi tahap 1 dilaksanakan di dua Posyandu Desa Mekarwangi yakni Posyandu Rambutan dan Posyandu Nusa Indah. Proses penjajakan kebutuhan bersama sebagaimana dijelaskan pada Gambar 3.

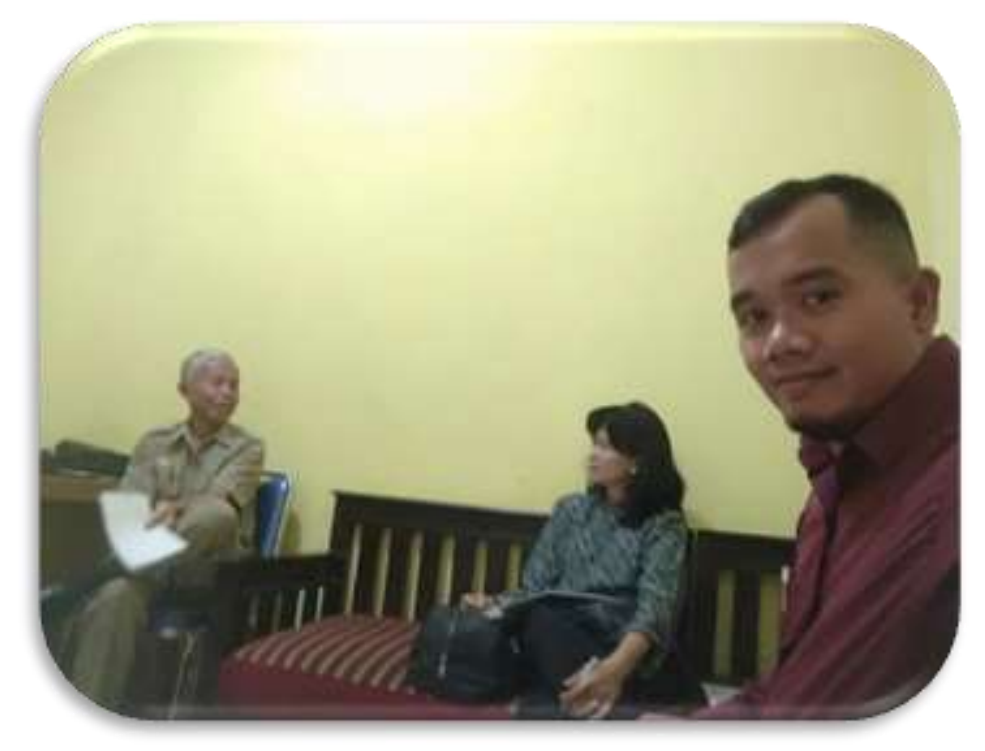

Gambar 3. Proses Penjajakan Kebutuhan Bersama PKM

Adapun persoalan prioritas yang disepakati untuk diselesaikan selama pelaksanaan program pengabdian kepada masyarakat di Posyandu Rambutan dan Posyandu Nanas Desa Mekarwangi adalah sebagai berikut:

a. Rendahnya pemahaman dan kemampuan pembukuan (akuntansi) bagi para Kader Posyandu Rambutan dan Posyandu Nusa Indah dikarenakan para kader tersebut mayoritas berpendidikan SD dan SMP; 
b. Keterlambatan penyampaian pelaporan pembukuan Posyandu Rambutan dan Posyandu Nusa Indah kepada Bidan dan Puskesmas Desa Mekarwangi;

c. Masih ditemukan data rekap pembukuan yang tidak valid dengan buku besar pembantu kegiatan Posyandu.

\section{Solusi}

Program Studi Akuntansi Universitas Matana memiliki keunggulan dalam konsentrasi keilmuan Akuntansi Sektor Publik dengan Dosen yang cukup kompeten di dalamnya melalui kegiatan implementasi RBTL (Research Based Teaching and Learning) dengan menggabungkan konsep pembelajaran Akuntansi Sektor Publik di Kelas (pertemuan 1-3) dengan pembelajaran aktual di Lapangan (pertemuan 4-14). Desa Mekarwangi merupakan salah satu Instansi Pemerintah, yang berdasarkan konsep Sektor Publik pada Pernyataan Standar Akuntansi Keuangan (PSAK) Nomor 45 merupakan Organisasi Nirlaba (Organisasi Non Profit) sehingga cocok digunakan sebagai tempat implementasi RBTL.

Melalui keunggulan di atas, tentu mampu dalam menyelesaikan permasalahan yang dihadapai oleh Mitra (Desa Mekarwangi) khususnya Posyandu Rambutan dan Posyandu Nusa Indah dengan solusi yang ditawarkan sebagai berikut:

a. Melakukan pra-survey pendahuluan ke Posyandu Rambutan dan Posyandu Nusa Indah untuk mengetahui kondisi kedua Posyandu tersebut khususnya dalam proses pembukuan dan merumuskan treatment dan tindakan pendampingan yang akan dilakukan;

b. Melakukan pendampingan pembukuan dua kali dalam seminggu selama 3 bulan;

c. Membuat improvement (tabel bantu berupa template) untuk mempermudah dan mempercepat proses pelaporan Posyandu.

Desain solusi pendampingan di atas diharapkan dapat meningkatkan beberapa kemampuan Para Kader Posyandu Rambutan dan Posyandu Nusa Indah dengan kemampuan berikut ini:

a. Pengetahuan mendasar tentang pembukuan (akuntansi) yang baik;

b. Menganalisa permasalahan dan kendala pembukuan yang dihadapi dengan perumusan solusi kritis yang dapat diimplementasikan dan bermanfaat dalam penyusunan pembukuan yang cepat dan efektif.

Adapun luaran yang ditargetkan dari kegiatan edukasi dan pendampingan akuntansi dalam kegiatan pengabdian kepada masyarakat ini meliputi:

a. Peningkatan pemahaman memadai mengenai pembukuan (akuntansi) bagi Para Kader Posyandu Rambutan dan Para Kader Posyandu Nusa Indah; 
b. Peningkatan kecepatan pelaporan pembukuan Posyandu kepada Bidan dan Puskesmas Desa Mekarwangi;

c. Peningkatan keakuratan pelaporan pembukuan Posyandu.

\section{Metode Pelaksanaan}

Objek kegiatan pengabdian kepada masyakat dengan judul "Edukasi dan Pendampingan Akuntansi Kader Posyandu Rambutan dan Posyandu Nusa Indah Desa Mekarwangi, Kabupaten Tangerang” Prodi Akuntansi Universitas Matana dilakukan di Posyandu Rambutan dan Posyandu Nusa Indah, Desa Mekarwangi, Cisauk, Tangerang.

Kegiatan pendampingan akuntansi akan direncanakan melalui beberapa langkah yang dijelaskan dalam roadmap pengabdian kepada masyarakat pada Gambar 4 di bawah ini:

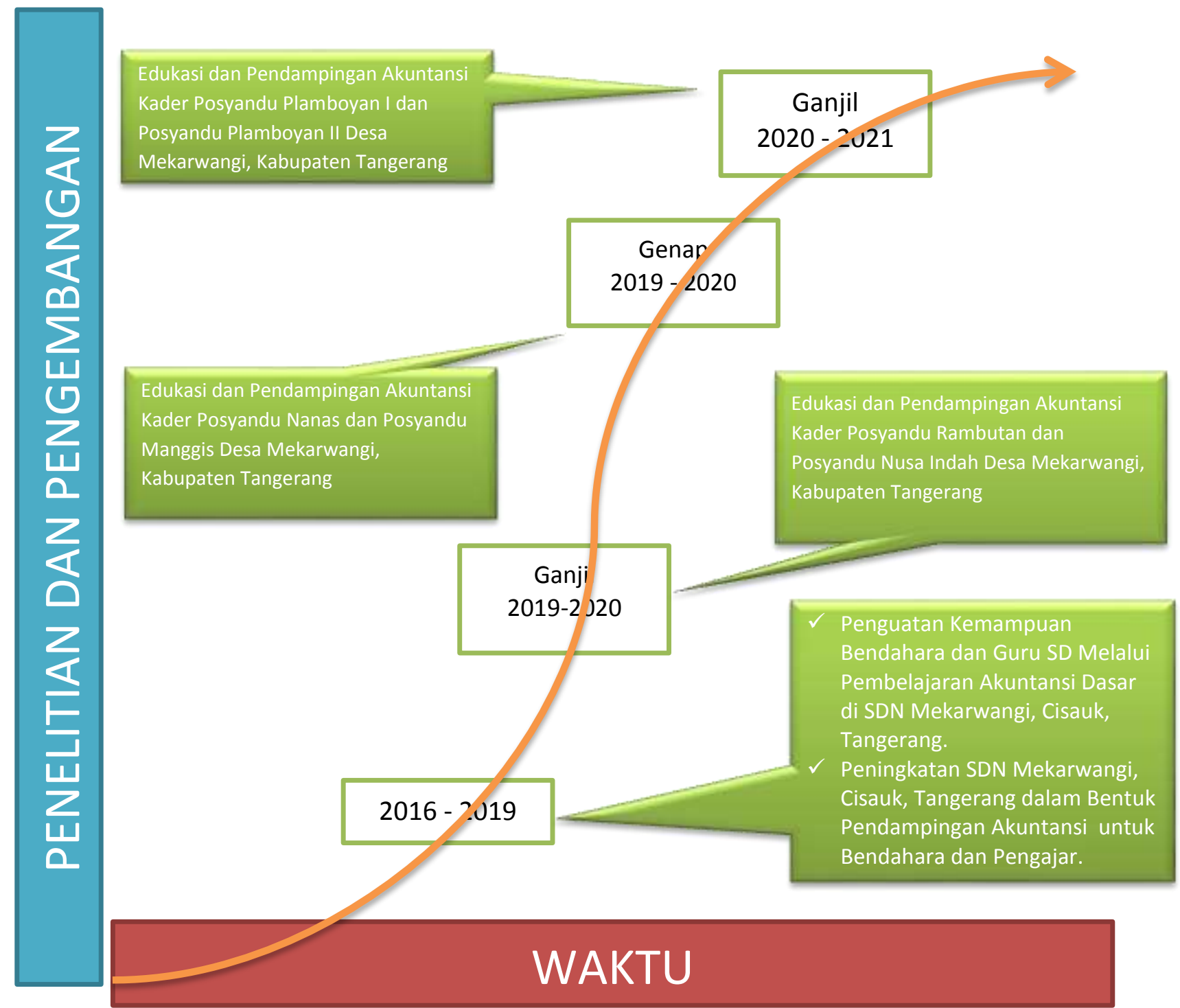

Gambar 4. Roadmap Kegiatan Pengabdian Kepada Masyarakat 
Kegiatan edukasi dan pendampingan akuntansi pada Posyandu Rambutan dan Posyandu Nusa Indah ini merupakan kegiatan yang bersifat terjadwal rutin sebagai kegiatan Pengabdian Kepada Masyarakat Program Studi Akuntansi Universitas Matana. Sesuai dengan kesepakatan dan kebutuhan Posyandu, maka pelaksanaan kegiatan pendampingan akan dilaksanakan 2 kali dalam 1 minggu, dengan rincian agenda pendampingan ditunjukkan melalui Tabel 1 berikut ini:

Tabel 1. Rencana Agenda Kegiatan Edukasi dan Pendampingan Akuntansi

\begin{tabular}{|c|c|}
\hline $\begin{array}{l}\text { Hari/ } \\
\text { Tanggal }\end{array}$ & $\begin{array}{l}\text { Rabu dan Jumat/ } \\
\text { 02 Oktober - 04 Desember } 2019\end{array}$ \\
\hline Pukul & $07.00-14.00 \mathrm{WIB}$ \\
\hline Peserta & $\begin{array}{l}\text { - } 5 \text { orang kader dari Posyandu Rambutan } \\
\text { - } 5 \text { orang kader dari Posyandu Nusa Indah }\end{array}$ \\
\hline Tempat & $\begin{array}{l}\text { - Posyandu Rambutan, Kp. Pasir Awi Rt. 14/05, Ds. Mekarwangi, } \\
\text { Kec. Cisauk; } \\
\text { - Posyandu Nusa Indah, Kp. Lebaksari Rt.10/05, Ds. Mekarwangi, } \\
\text { Kec. Cisauk. }\end{array}$ \\
\hline Agenda & $\begin{array}{l}\text { Edukasi dan Pendampingan Akuntansi untuk Kader Posyandu } \\
\text { Rambutan dan Posyandu Nusa Indah }\end{array}$ \\
\hline Instruktur & $\begin{array}{l}\text { Dosen Pembina: } \\
\text { Bahtiar Effendi, S.E., M.Ak., CSRS., CSP. (NIDN. 0301019003) } \\
\begin{array}{ll}\text { Mahasiswa: } \\
\text { 1. } \quad \text { Amelia (NIM. 20176220001); } \\
\text { 2. } \quad \text { Cynthia (NIM. 20176220004); } \\
\text { 3. } \quad \text { Reyvan (NIM. 20176220006); } \\
\text { 4. } \quad \text { Clara (NIM. 20176220010); } \\
\text { 5. } \quad \text { Gloria (NIM. 20176220011); } \\
6 . \quad \text { Vonny (NIM. 20176220012); } \\
\text { 7. } & \text { Adella (NIM. 20176220015); } \\
8 . & \text { Stephanie (NIM. 20176220019); } \\
9 . & \text { Kelvin Yanuar (NIM. 20176220021); } \\
\text { 10. } & \text { Oxsa (NIM. 20176220022); } \\
\text { 11. } & \text { Buddhi (NIM. 20176220025); } \\
\text { 12. } & \text { Rika (NIM. 20176220035); } \\
\text { 13. } & \text { Edrya Dwi Edla (NIM. 20176220037). }\end{array}\end{array}$ \\
\hline
\end{tabular}

\section{Hasil dan Pembahasan}

Proses pembelajaran merupakan suatu proses komprehensif yang ditujukan dalam perubahan perilaku seorang individu (Agus Suprijono (2011, p.4-5). Pembelajaran sendiri tidak akan terlepas 
dari kegiatan pendampingan. Posyandu yang merupakan kegiatan swadaya dari masyarakat di bidang kesehatan dengan penangungjawab kepala desa diharapkan dapat meningkatkan kesehatan masyarakat khususnya ibu hamil, batita dan balita. Organisasi ini tentu perlu didukung oleh keterlibatan beberapa Pihak khususnya institusi pendidikan. Universitas menjadi tonggak terpenting dalam implemetasi kegiatan pengabdian kepada masyarakat yang diwajibkan dalam Tri Dharma Perguruan Tinggi.

Kegiatan pengabdian kepada masyarakat melalui kegiatan edukasi dan pendampingan akuntansi di Posyandu Rambutan dan Posyandu Nusa Indah ini dilakukan melalui kegiatan pendampingan terkait dengan proses pencatatan pembukuan (akuntansi) Posyandu dari mulai proses pendataan peserta Posyandu hingga proses pelaporan baik terkait informasi keuangan dan informasi non keuangan ke Puskesmas dan Desa Mekarwangi. Tujuan dari kegiatan pendampingan dalam Posyandu ini adalah untuk meningkatkan pemahaman memadai mengenai pembukuan (akuntansi) bagi Para Kader Posyandu dalam proses pencatatan dan pembukuan yang efektif dan efisien. Selanjutnya, kegiatan pendampingan ini juga bertujuan untuk meningkatkan kecepatan dan keakuratan pelaporan pembukuan bagi Para Kader Posyandu baik informasi keuangan maupun non keuangan untuk pihak internal dan pihak eksternal.
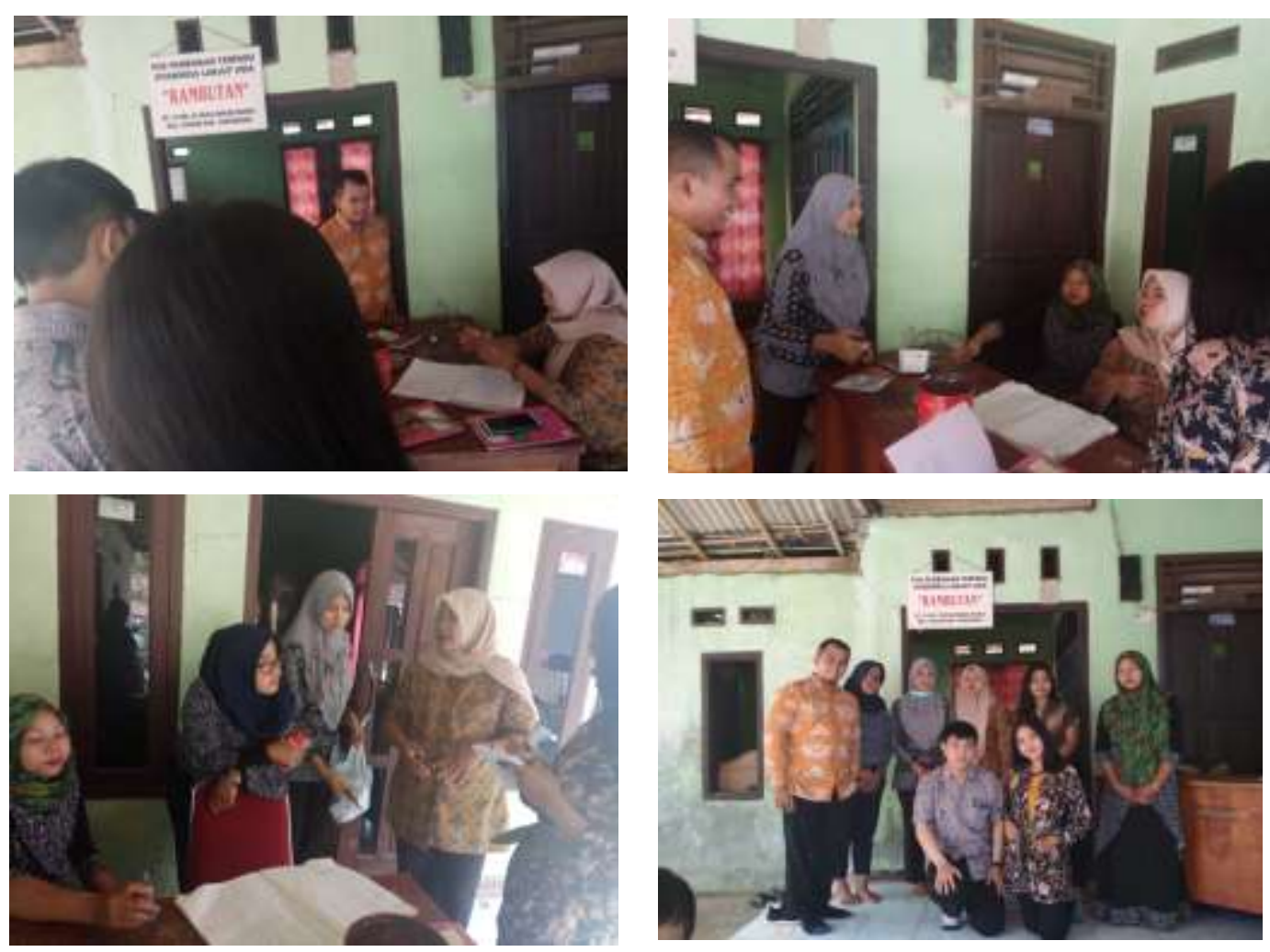

Gambar 5. Proses Edukasi dan Pendampingan Akuntansi Posyandu Rambutan (Kp. Pasir Awi, Rt. 14/05, Ds. Mekarwangi, Kec. Cisauk) 
Posyandu Rambutan berlokasi di Kampung Pasir Awi, Rt. 14, Rw. 005, Desa Mekarwangi, Kecamatan Cisauk, Kabupaten Tangerang. Kegiatan di Posyandu Rambutan berisi Posyandu untuk Ibu Hamil, Batita dan Balita serta dimulai dari pukul 07.30-13.30 WIB dengan pelayanan 4 Kader dan 1 Bidan Desa. Adapun jarak tempuh antara Universitas Matana menuju Posyandu Rambutan sejauh 19,4 km dengan waktu tempuh mencapai 41 menit dikarenakan jalan yang kurang baik. Proses pendampingan pembukuan yang dilakukan di Posyandu Rambutan ini dilakukan melalui proses rekapitulasi semua aspek pencatatan posyandu yang meliputi nama anak kandung, nama ibu, berat badan, umur, peningkatan dan penurunan berat badan, jenis kelamin, dan pemberian imunisasi dan diakhiri dengan proses pendampingan pelaporan ke beberapa format berikut ini: Format 1 (Ibu Hamil), Format 2 (Balita di bawah 1 tahun) dan Format 3 (Balita di atas 1 tahun). Adapun proses edukasi dan pendampingan akuntansi lebih lengkap telah dijelaskan dalam Gambar 5 di atas.
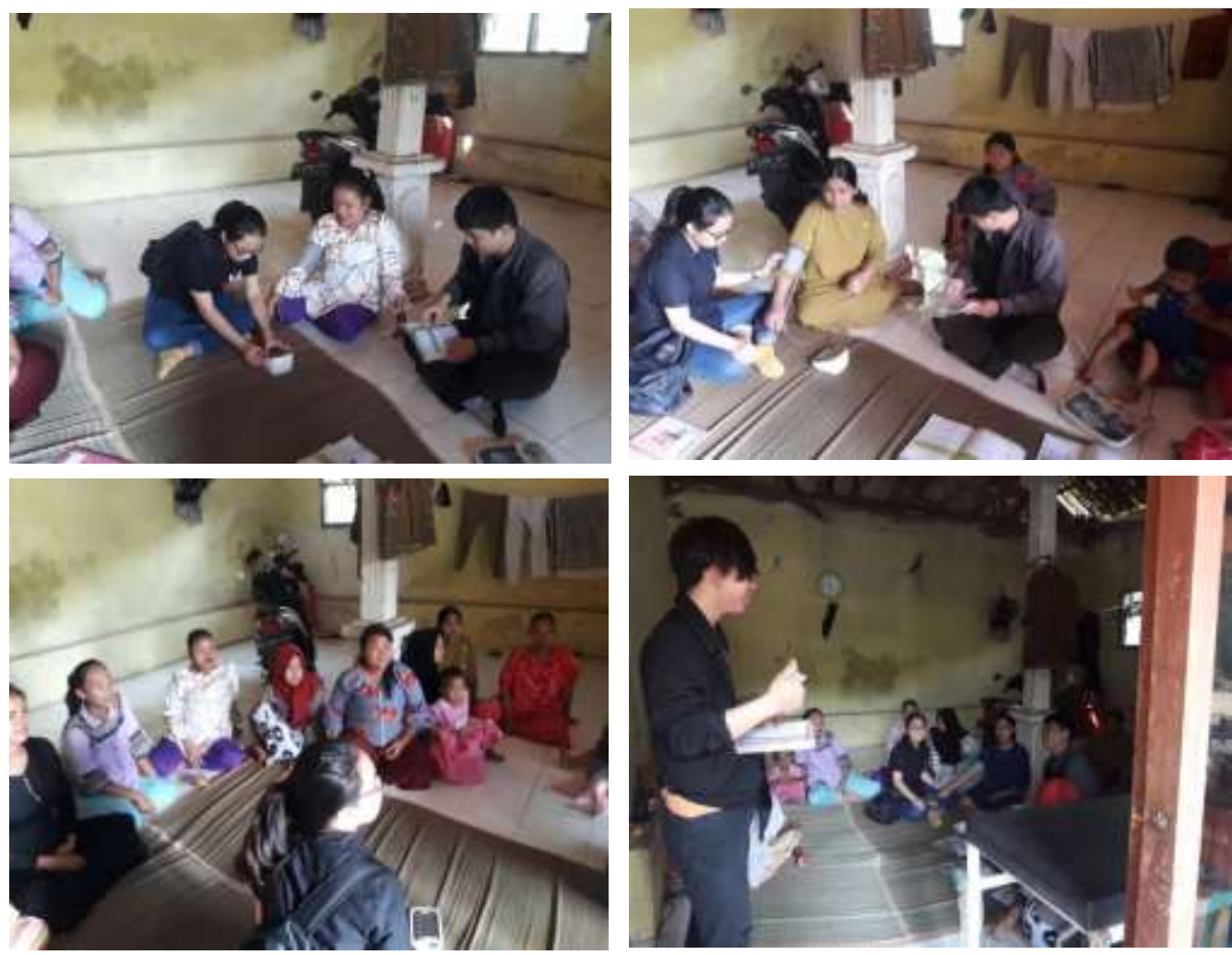

Gambar 6. Proses Edukasi dan Pendampingan Akuntansi Posyandu Nusa Indah (Kp. Lebaksari, Rt. 10/05, Ds. Mekarwangi, Kec. Cisauk)

Kegiatan edukasi dan pendampingan akuntansi selanjutnya dilakukan pada Posyandu Nusa Indah. Posyandu ini berlokasi di Kampung Lebaksari Rt. 10, Rw. 05, Desa Mekarwangi, Kecamatan Cisauk, Kabupaten Tangerang. Kegiatan posyandu dimulai dari pukul 08.00-13.00 WIB. Adapun jarak tempuh dari Universitas Matana menuju Posyandu Manggis adalah 19,4 km dengan waktu tempuh mencapai 53 menit. Proses edukasi dan pendampingan akuntansi yang 
dilakukan di Posyandu Nusa Indah ini, hampir sama dengan kegiatan edukasi dan pendampingan akuntansi pada Posyandu Rambutan yakni proses edukasi dan pendampingan terkait dengan rekapitulasi: nama anak kandung, nama ibu, berat badan, umur, peningkatan dan penurunan berat badan, jenis kelamin, dan pemberian imunisasi dan diakhiri dengan proses posting dari buku pembantu menuju beberapa Format 1 (Ibu Hamil), Format 2 (Balita di bawah 1 tahun) dan Format 3 (Balita di atas 1 tahun) dan kertas kerja rekapan akhir yang akan dilaporkan kepada Bidan dan Desa Mekarwangi. Adapun proses edukasi dan pendampingan di Posyandu Nusa Indah ini telah dijelaskan lebih detail pada Gambar 6 di atas.

Secara garis besar, kegiatan edukasi dan pendampingan akuntansi untuk Posyandu Rambutan dan Posyandu Nusa Indah Desa Mekarwangi, Cisauk, Tangerang yang telah dilakukan dari tanggal 2 oktober hingga 04 desember 2019 mendapatkan hasil sebagai berikut:

1. Ditemukan adanya peningkatan pemahaman memadai mengenai pembukuan (akuntansi) bagi Para Kader Posyandu;

2. Ditemukan adanya tabel pencatatan pembantu (hasil analisis Tim PKM) untuk mempermudah proses rekapitulasi dari buku manual ke 5 format buku kegiatan Posyandu sebagai berikut:

\begin{tabular}{|l|l|l|l|l|l|l|l|l|l|l|}
\hline \multicolumn{1}{|c|}{$\begin{array}{c}\text { USIA } \\
(\text { BLN) }\end{array}$} & \multicolumn{2}{|c|}{ N } & \multicolumn{2}{c|}{ T } & \multicolumn{2}{c|}{ T2 } & \multicolumn{2}{c|}{ O } & \multicolumn{2}{c|}{ B } \\
\hline & L & P & L & P & L & P & L & P & L & P \\
\hline $0-5$ & & & & & & & & & & \\
\hline $6-11$ & & & & & & & & & & \\
\hline $12-23$ & & & & & & & & & & \\
\hline $24-35$ & & & & & & & & & & \\
\hline $36-59$ & & & & & & & & & & \\
\hline Total & & & & & & & & & & \\
\hline
\end{tabular}

Keterangan:
$\mathrm{N}$ : Naik berat badan
T2: Turun dua kali berat badan
B: Peserta Baru
$\mathrm{T}$ : Turun berat badan
O: Kosong (tidak hadir pada Posyandu waktu sebelumnya)

3. Terdapat peningkatan kecepatan dan keakuratan pembukuan bagi Para Kader masing-masing Posyandu dalam pelaporan kegiatan posyandu baik terkait dengan laporan pembukuan keuangan maupun non keuangan kepada Bidan maupun Kantor Desa Mekarwangi (berdasarkan hasil pre test, wawancara langsung dengan Bidan Desa pada hari Rabu, tanggal 04 Desember 2019). 


\section{Kesimpulan}

Kegiatan pengabdian kepada masyarakat ini berupaya untuk memberikan penguatan bagi Posyandu Rambutan dan Posyandu Nusa Indah, Desa Mekarwangi, Cisauk, Tangerang melalui kegiatan edukasi dan pendampingan akuntansi bagi Kader Posyandu. Kegiatan edukasi dan pendampingan akuntansi yang dilaksanakan di Posyandu Rambutan dan Posyandu Nusa Indah ini merupakan kegiatan yang dilaksankan atas dasar arahan dan masukkan dari hasil penjajakan kebutuhan bersama antara Pihak Universitas Matana dengan Pihak Desa Mekarwangi (diwakili oleh Bp Dali/ SekDes Mekarwangi) yang telah dilaksanakan pada tanggal 13 Agustus 2019. Kegiatan edukasi dan pendampingan akuntansi bagi Posyandu telah dilaksanakan dari tanggal 2 Oktober hingga 4 Desember 2019.

Hasil dari kegiatan edukasi dan pendampingan akuntansi bagi Posyandu Rambutan dan Posyandu Nusa Indah ini cukup efektif dalam rangka peningkatan pemahaman memadai mengenai pembukuan (akuntansi) yang baik dan benar dan berdasarkan hasil dari perumusan dan analisa antara Dosen dan Mahasiswa mengenai pembukuan Posyandu yang sedang berjalan berhasil memberikan kontribusi template tabel bantu yang terbukti membantu dan mempercepat proses pembukuan Posyandu sehingga pelaporan kegiatan Posyandu dapat disampaikan akurat dan tepat waktu.

Rekomendasi kegiatan pengabdian kepada masyarakat selanjutnya, diharapkan dapat memberikan edukasi dan pendampingan akuntansi kembali kepada para kader Posyandu lainnya di Desa Mekarwangi, Cisauk, Tangerang.

\section{Pernyataan}

Terima kasih kepada Universitas Matana yang telah memberikan kesempatan dalam pengumpulan data dan mendukung proses penelitian ini. Terima kasih juga kepada semua pihak yang terlibat dalam persiapan, peninjauan, analisis, dan revisi. Semoga bermanfaat bagi kegiatan pengabdian kepada masyarakat di masa depan.

\section{Referensi}

Agus, S. (2011). “Model-Model Pembelajaran”. Jakarta: Gramedia Pustaka Jaya.Agus Suprijono (2011, p.4-5).

Anonim. (2015). "Buku Monograf Desa Mekarwangi".

Bambang, S. (2018). "Desa Dang Dang dan Mekarwangi Sedang Melaksanakan Program P2WKSS”. Onlinebuser.com. [diakses 11 september 2019]. https://onlinebuser.com/lintasdaerah/desa-dang-dang-dan-mekarwangi-sedang-melaksanakan-program-p2wkss/ 
Effendi, B. (2018). "Penguatan Kemampuan Bendahara dan Guru SD Melalui Pembelajaran Akuntansi Dasar di SDN Mekarwangi, Ds. Mekarwangi, Kec. Cisauk, Tangerang-Banten”. Jurnal Terapan Abdimas. (Volume 3, No.2; 188-191).

Effendi, B. (2019). "Accounting Assistance for Treasurers and Teachers for Improvement and Strengthening of Mekarwangi Elementary School, Cisauk, Tangerang [Peningkatan dan Penguatan SDN Mekarwangi, Cisauk, Tangerang Dalam Bentuk Pendampingan Akuntansi Untuk Bendahara dan Pengajar]". Proceeding of Community Development. (Volume 2; 225233).

Keputusan Menteri Pemberdayaan Perempuan Republik Indonesia No. 41 Tahun 2007 tentang Pedoman Umum Revitalisasi Program Terpadu P2WKSS.

Suharto, Edi. (2009). "Membangun Masyarakat Memberdayakan Rakyat: Kajian Strategis Pembangunan Kesejahteraan Sosial dan Pekerjaan Sosial”. Bandung: Refika Aditama.

Undang-Undang Nomor 11 Tahun 2009 tentang Kesejahteraan Sosial. 